\title{
EJNSO
}

\section{Half-thickness tragal cartilage slicing improves the sound transmission properties in endoscopic myringoplasty among Egyptians}

\author{
Ahmed A. Sadek, and Mostafa M. Talaat \\ Otorhinolaryngology Department, Faculty of Medicine, Minia University, \\ Minia 61511, Egypt.
}

\begin{abstract}
Purpose: To compare full and half thickness tragal cartilage in endoscopic myringoplasty by using cartilage slicer.

Patients and Methods: This study was conducted at the ENT Department at Minia University Hospital and included 32 patients with chronic suppurative otitis media attending the E.N.T. outpatient clinic. The Patients were divided into two groups, 16 patients were included in group A, where a half thickness tragal cartilage graft was used and 16 patients included in group B where a full thickness tragal cartilage graft was used for myringoplasty. Underlay graft technique was used in all cases by endoscopic assisted transcanal myringoplasty.

Result: The graft was taken in 30 patients, 15 in each, so the graft takes up rate is $93.8 \%$ in both groups. Difference in hearing gain was not statistically significant between the two groups, except at 4,000 Hz; where hearing gain in half thickness tragal cartilage (Group A) is more than full thickness tragal cartilage (Group B). For both groups, hearing gain was more at $250,500 \mathrm{~Hz}$ than at1000, 2000, 4000 and $8000 \mathrm{~Hz}$ frequencies .

Conclusion: Our data show that slicing of the tragal cartilage into half $(0.5 \mathrm{~mm})$ is suitable to improve the sound transmission properties of the reconstructed tympanic membrane in comparison to the full thickness tragal cartilage $(1.0 \mathrm{~mm})$.
\end{abstract}

Keywords: Cartilage Slicer - Chronic Suppurative Otitis Media - Endoscopic Transcanal Myringoplasty- Tragal cartilage.

\section{Introduction}

Cartilages have been shown as a promising graft material to close perforations in the tympanic membrane. ${ }^{1}$ Since the tragus is within the field of surgery, the tissue is readily available. With the proper technique, its removal causes no scarring or deformation. $^{2}$ Tragal and conchal cartilages are most frequently used for this purpose. Studies have shown that slicing the cartilage to less than 0.5

mm thickness improves acoustic benefits. ${ }^{3}$

In order to prevent thick cartilage interfering with sound conduction, some authors ${ }^{3}$ prefer to slice the tragal cartilage. Different techniques to split the thickness of tragal cartilage have been reported. In this technique of cartilage-perichondrium composite graft tympanoplasty, they split the tragal cartilage with a precise mathematical Kurz ${ }^{\circledR}$ Precise Cartilage 
Splitter to attain cartilage of a definite thickness. ${ }^{4}$

Hand slicing a harvested cartilage into thin slices with a homogeneous thickness is extremely difficult. This difficulty has prompted surgeons to employ devices for this purpose. Growing experience in cartilage tympanoplasty has led to the design of a cartilage slicer. This slicer has some key features, including a durable unibody design, the ability to slice cartilage without damage, ease of use, adjustable cartilage thickness options, and low cost and practicality. ${ }^{5}$

In this study, we compared sound transmission properties after full- and half thickness tragal cartilage in endoscopic myringoplasty by using a cartilage slicer among Egyptian patients.

\section{Patients and Methods:}

This study was conducted at the ENT department at Minia University Hospital and included 32 patients with chronic suppurative otitis media who attended the E.N.T. outpatient clinic at the Hospital in the period from February 2017 to November 2017.

The patients were divided into two groups. 16 patients were included in group $\mathrm{A}$, where a half thickness tragal cartilage graft was used and 16 patients included in group B where a full thickness tragal cartilage graft was used for myringoplasty. Underlay graft technique was used in all cases by endoscopic assisted transcanal myringoplasty.

\section{Technique:}

Cartilages were harvested through a 4- to 5-mm incision performed 2- to 3$\mathrm{mm}$ medial to the tragal cartilage's free border, after the skin was infiltrated using adrenaline dissolved in saline at a concentration of $1: 200,000$, incising the skin and the cartilage. The cartilage was freed of the perichondrium and elevated at the external auditory canal (EAC) aspect of the cartilage. On the opposite side, the perichondrium was left attached to the cartilage, and a 3to 4-mm-sized cartilage was removed with its perichondrium attached on one side, the other side of it being uncovered by perichondrium.

The incision was sutured with an absorbable material. The ear canal-side of the cartilage is concave. Therefore, this side was preferably placed towards the middle ear. Perforation edges and anterior annulus were visualized with a $0^{\circ}, 2.7 \mathrm{~mm} \times 9 \mathrm{~cm}$ rigid endoscope. The edges of the perforation were refreshed with an angled pick. Through incision was made along the edges of perforation and the ring of epithelium removed, along with a strip mucosal layer from the inner side of the perforation .

Under endoscopic vision, the middle ear was tightly packed with gelfoam through the perforation, until the level of the perforation. The tubal orifice was supported more tightly in order to prevent medialization due to negative pressure produced by sniffing. Later, the graft was prepared 1-2 $\mathrm{mm}$ larger than the perforation. The tragal cartilage was not thinned out and used as a graft at its natural thickness in group B as shown in Figure (1).

While a half thickness tragal cartilage graft was used in group A, the average thickness of the tragal cartilage reported is $1 \mathrm{~mm}$. So, we prefer to slice the tragal cartilage. There are different techniques to split the thickness of tragal cartilage. In our technique, we splitted the tragal cartilage with a precise mathematical Kurz ${ }^{\circledR}$ Precise Cartilage Splitter to attain cartilage of a definite thickness. This cartilage splitter consists of metallic distance plates of $0.1,0.2,0.3$ and $0.5 \mathrm{~mm}$ thickness, which give the expected respective thickness of slices as shown in Figures 2, and 3. 
In our study, we used $0.5 \mathrm{~mm}$ plate to obtain a half thickness tragal cartilage graft in group A. Then the cartilage graft was pushed through the perforation, and placed in an underlay fashion, its concave and perichondrium - free surface looking towards the middle ear. It was covered with gelfoams until the level of the isthmus. The patients were discharged on the day of the surgery .

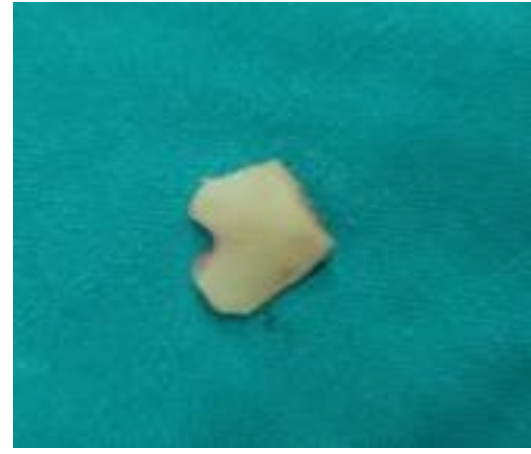

Fig.1. A full thickness tragal cartilage graft.

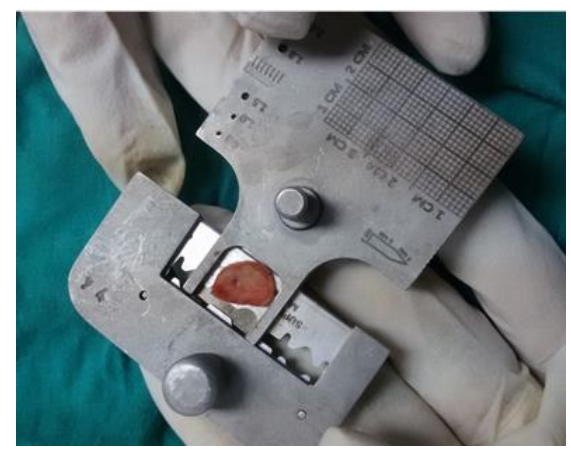

Fig.2. Tragal cartilage slicing technique, performed using a Kurz ${ }^{\circledR}$ Precise Cartilage Slicer.

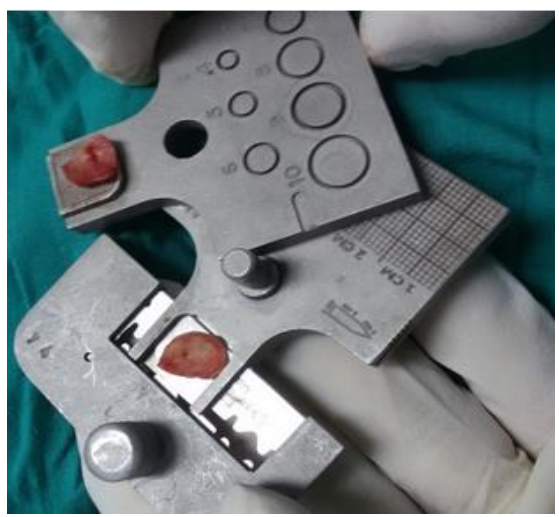

Fig.3. Sliced tragal cartilage, in two parts.
The patients were given oral antibiotics and decongestant in the first post-operative week, as well as nonsteroidal anti-inflammatory agents, as needed.

Patients were followed weekly in the first month to evaluate the status of the graft. Then, the patients were followed up at post-operative 2nd, and 3rd months using endoscopic examination and pure tone audiometry (PTA) was done in the 3rd month.

\section{Statistical analysis:}

The collected data were revised, organized, tabulated and statistically analyzed. The results were analyzed statistically, using ChiSquare Test and Student t-test, using SPSS III software.

$\mathrm{P}$ value of less than 0.05 was considered significant and less than 0.001 as highly significant.

\section{Results:}

The graft success was achieved in 30 patients, 15 patients in each group. So, the graft success rate was $93.8 \%$ for both groups. No lateralization or medialization was seen in the successful cases. The demographic characteristics of both groups with no statistical difference between both groups in age and sex are shown in Table 1. In this regard, in group $A$, the mean age of the patients was $25.2 \pm 6.9$ years with predominance of females representing $(73.3 \%)$. In group $B$, the mean age of the patients was 22.6 \pm 8.6 years with females representing $(66.7 \%)$. 
Table (1): Comparison between the two groups regarding demographic data.

\begin{tabular}{|l|c|c|c|}
\hline $\begin{array}{l}\text { Demographic } \\
\text { data }\end{array}$ & $\begin{array}{c}\text { Group A } \\
\text { Half } \\
\text { thickness } \\
\text { grafts } \\
(\mathbf{n = 1 5})\end{array}$ & $\begin{array}{c}\text { Group B } \\
\text { Full } \\
\text { thickness } \\
\text { graft } \\
(\mathbf{n = 1 5})\end{array}$ & \multirow{2}{*}{$\begin{array}{c}\text { P - } \\
\text { value }\end{array}$} \\
\hline \multirow{2}{*}{$\begin{array}{c}\text { Age } \\
\text { Range } \\
\text { Mean } \pm \text { SD } \\
\text { Median }\end{array}$} & $14-36$ & $12-42$ & \multirow{2}{*}{0.217} \\
\cline { 2 - 3 } & $25.2 \pm 6.9$ & $22.6 \pm 8.6$ & \\
\cline { 2 - 3 } $\begin{array}{c}\text { Sex } \\
\text { Male } \\
\text { Female }\end{array}$ & 26 & 20 & \\
\cline { 2 - 3 } 0 & $4(26.7 \%)$ & $5(33.3 \%)$ & \\
\cline { 2 - 3 } & $11(73.3 \%)$ & $10(66.7 \%)$ & \\
\hline
\end{tabular}

Mann-Whiteny test was used for quantitative data, while chi-square test was used for qualitative data.

The frequency of air conduction (AC) threshold pre-operatively was not significantly different between the two groups in all frequencies tested ranging from $250-8000 \mathrm{~Hz}$ (Table 2).

AC threshold frequency postoperatively in both groups which was significantly different only at frequencies of 2000 and $4000 \mathrm{~Hz}$. In this regard, in Group A, the mean AC threshold frequency at 2000 and 4000 $\mathrm{Hz}$ was $24 \pm 2.1$ and $25 \pm 6.5$ while that of group B was $34 \pm 9.7$ and $36 \pm 15.4$, respectively (Table 3 ).

There was a significant postoperative improvement in PTA and hearing in patients of group A where a half thickness tragal cartilage graft $(0.5 \mathrm{~mm})$ was used for myringoplasty at all frequencies tested ( $\mathrm{p}=0.001$; Table 4). The same applies when we compare pre- and post-operative AC threshold in patients of group B; where a full thickness tragal cartilage graft $(1 \mathrm{~mm})$ was used for myringoplasty at all frequencies tested $(\mathrm{p}=0.001$; Table 5).

There was a hearing gain in both groups. These gain values represented in terms of reduction in air bone gap (ABG), no worsening of bone conduction threshold indicative of sensory-neural hearing loss was seen in any of the cases. It is apparent that hearing gain is maximum at frequencies of 250 and $500 \mathrm{~Hz}$ in both groups, but in frequencies 1000, 2000, 4000 and $8000 \mathrm{~Hz}$, hearing gain is less. The difference of hearing gain, between group $\mathrm{A}$ and $\mathrm{B}$ at all frequencies was not statistically significant except at $4000 \mathrm{~Hz}$ $(\mathrm{p}=0.037$; table 6$)$.

\section{Discussion :}

In this study, we show improvement of hearing and sound transmission properties after using half and full thickness tragal cartilage using cartilage slicer among Egyptian patients.

Cartilages were first introduced in middle ear surgery in 1959 and has recently been used by several otologists for reconstruction of the tympanic membrane, as an underlay graft with perichondrium adjacent to the tympanic membrane remnant. ${ }^{6}$

One study compared different cartilage techniques and reported that; from an acoustical point of view; the $0.5-\mathrm{mm}$ cartilage plate seems preferable compared with the palisade technique. ${ }^{7}$

Another study concluded that tympanoplasty using cartilage with or without perichondrium has better morphological outcome than tympanoplasty using temporalis fascia. However, there was no statistically significant difference in hearing outcomes between the two grafts. ${ }^{8}$

A cartilage plate-tympanic membrane coupled model using high-resolution computed tomography and finite element analysis and from the study concluded that the optimal thickness of a cartilage graft for myringoplasty appears to be $0.1-0.2 \mathrm{~mm}$ for medium and large TM perforations. ${ }^{9}$ Concerns that the stiffness and mass of cartilage grafts may adversely affect hearing have not been substantiated in clinical reports thus far. ${ }^{10}$ 
Table (2): Comparison between the two groups regarding preoperative pure tone audiometry.

\begin{tabular}{|c|c|c|c|}
\hline $\begin{array}{l}\text { Preoperative pure tone } \\
\text { audiometry frequency }(\mathrm{Hz})\end{array}$ & $\begin{array}{l}\text { Group A } \\
\text { Half thickness graft }(n=15)\end{array}$ & $\begin{array}{c}\text { Group B } \\
\text { Full thickness graft }(n=15)\end{array}$ & $P$ - value \\
\hline $\begin{array}{l}250 ~ H z \\
\text { Range } \\
\text { Mean } \pm \text { SD } \\
\text { Median }\end{array}$ & $\begin{array}{c}40-60 \\
49.3 \pm 6.2 \\
50\end{array}$ & $\begin{array}{c}35-60 \\
48.3 \pm 8.8 \\
50\end{array}$ & 0.744 \\
\hline $\begin{array}{l}\mathbf{5 0 0 ~ H z} \\
\text { Range } \\
\text { Mean } \pm \text { SD } \\
\text { Median } \\
\end{array}$ & $\begin{array}{c}40-55 \\
47.3 \pm 4.6 \\
45 \\
\end{array}$ & $\begin{array}{c}25-60 \\
46.3 \pm 12.4 \\
50 \\
\end{array}$ & 0.412 \\
\hline $\begin{array}{l}\mathbf{1 0 0 0 ~ H z} \\
\text { Range } \\
\text { Mean } \pm \text { SD } \\
\text { Median }\end{array}$ & $\begin{array}{c}20-45 \\
39 \pm 8.7 \\
45\end{array}$ & $\begin{array}{c}25-50 \\
41.3 \pm 10 \\
45\end{array}$ & 0.202 \\
\hline $\begin{array}{l}2000 ~ H z \\
\text { Range } \\
\text { Mean } \pm \text { SD } \\
\text { Median }\end{array}$ & $\begin{array}{c}20-40 \\
34 \pm 7.4 \\
40\end{array}$ & $\begin{array}{c}30-70 \\
43.3 \pm 13.2 \\
40\end{array}$ & 0.089 \\
\hline $\begin{array}{l}\mathbf{4 0 0 0 ~ H z} \\
\text { Range } \\
\text { Mean } \pm \text { SD } \\
\text { Median } \\
\end{array}$ & $\begin{array}{c}25-50 \\
38.7 \pm 8.5 \\
40 \\
\end{array}$ & $\begin{array}{c}30-70 \\
46.6 \pm 15.2 \\
40 \\
\end{array}$ & 0.233 \\
\hline $\begin{array}{l}8000 ~ H z \\
\text { Range } \\
\text { Mean } \pm \text { SD } \\
\text { Median } \\
\end{array}$ & $\begin{array}{c}30-50 \\
44 \pm 5.4 \\
45\end{array}$ & $\begin{array}{c}35-90 \\
54 \pm 24 \\
40\end{array}$ & 0.155 \\
\hline
\end{tabular}

Mann-Whiteny test was used for quantitative data

Table (3): Comparison between the two groups regarding post-operative pure tone audiometry.

\begin{tabular}{|c|c|c|c|}
\hline $\begin{array}{c}\text { Postoperative pure tone } \\
\text { audiometry frequency }(\mathrm{Hz})\end{array}$ & $\begin{array}{c}\text { Group A } \\
\text { Half thickness graft }(n=15)\end{array}$ & $\begin{array}{c}\text { Group B } \\
\text { Full thickness graft }(n=15)\end{array}$ & $P$ - value \\
\hline $\begin{array}{l}250 ~ H z \\
\text { Range } \\
\text { Mean } \pm \text { SD } \\
\text { Median } \\
\end{array}$ & $\begin{array}{c}25-40 \\
33 \pm 6.5 \\
30\end{array}$ & $\begin{array}{c}25-40 \\
33 \pm 6.8 \\
35\end{array}$ & 0.967 \\
\hline $\begin{array}{l}\mathbf{5 0 0} \mathbf{~ H z} \\
\text { Range } \\
\text { Mean } \pm \text { SD } \\
\text { Median } \\
\end{array}$ & $\begin{array}{c}25-35 \\
29 \pm 3.8 \\
30 \\
\end{array}$ & $\begin{array}{c}20-45 \\
31.3 \pm 8.1 \\
35 \\
\end{array}$ & 0.367 \\
\hline $\begin{array}{l}1000 ~ H z \\
\text { Range } \\
\text { Mean } \pm \text { SD } \\
\text { Median } \\
\end{array}$ & $\begin{array}{c}20-35 \\
29 \pm 6.3 \\
30 \\
\end{array}$ & $\begin{array}{c}20-40 \\
30.6 \pm 7 \\
35 \\
\end{array}$ & 0.461 \\
\hline $\begin{array}{l}2000 \text { Hz } \\
\text { Range } \\
\text { Mean } \pm \text { SD } \\
\text { Median } \\
\end{array}$ & $\begin{array}{c}20-25 \\
24 \pm 2.1 \\
25 \\
\end{array}$ & $\begin{array}{c}20-55 \\
34 \pm 9.7 \\
35 \\
\end{array}$ & $0.001 *$ \\
\hline $\begin{array}{l}\mathbf{4 0 0 0 ~ H z} \\
\text { Range } \\
\text { Mean } \pm \text { SD } \\
\text { Median } \\
\end{array}$ & $\begin{array}{c}20-35 \\
25 \pm 6.5 \\
20\end{array}$ & $\begin{array}{c}25-65 \\
36 \pm 15.4 \\
30 \\
\end{array}$ & $0.013^{*}$ \\
\hline $\begin{array}{l}\mathbf{8 0 0 0 ~ H z} \\
\text { Range } \\
\text { Mean } \pm \text { SD } \\
\text { Median } \\
\end{array}$ & $\begin{array}{c}20-50 \\
32.6 \pm 9.4 \\
30 \\
\end{array}$ & $\begin{array}{c}25-80 \\
45 \pm 22.4 \\
35 \\
\end{array}$ & 0.174 \\
\hline
\end{tabular}

Mann-Whiteny test was used for quantitative data

*: Significant difference in between groups ( $\mathrm{p}$ value $\leq 0.05$ ) 
Table (4): Comparison between preoperative and postoperative pure tone audiometry in group A (n=15).

\begin{tabular}{|c|c|c|c|}
\hline Frequency $(\mathrm{Hz})$ & $\begin{array}{c}\text { Preoperative pure tone } \\
\text { audiometry }\end{array}$ & $\begin{array}{c}\text { Postoperative pure tone } \\
\text { audiometry }\end{array}$ & $P$ - value \\
\hline $\begin{array}{l}\mathbf{2 5 0} \mathbf{~ H z} \\
\text { Range } \\
\text { Mean } \pm \text { SD } \\
\text { Median } \\
\end{array}$ & $\begin{array}{c}40-60 \\
49.3 \pm 6.2 \\
50 \\
\end{array}$ & $\begin{array}{c}25-40 \\
33 \pm 6.5 \\
30 \\
\end{array}$ & $0.001 *$ \\
\hline $\begin{array}{l}\mathbf{5 0 0} \mathbf{~ H z} \\
\text { Range } \\
\text { Mean } \pm \text { SD } \\
\text { Median }\end{array}$ & $\begin{array}{c}40-55 \\
47.3 \pm 4.6 \\
45\end{array}$ & $\begin{array}{c}25-35 \\
29 \pm 3.8 \\
30\end{array}$ & $0.001 *$ \\
\hline $\begin{array}{l}\mathbf{1 0 0 0 ~ H z} \\
\text { Range } \\
\text { Mean } \pm \text { SD } \\
\text { Median }\end{array}$ & $\begin{array}{c}20-45 \\
39 \pm 8.7 \\
45\end{array}$ & $\begin{array}{c}20-35 \\
29 \pm 6.3 \\
30\end{array}$ & $0.001 *$ \\
\hline $\begin{array}{l}\mathbf{2 0 0 0} \mathbf{H z} \\
\text { Range } \\
\text { Mean } \pm \text { SD } \\
\text { Median } \\
\end{array}$ & $\begin{array}{c}20-40 \\
34 \pm 7.4 \\
40\end{array}$ & $\begin{array}{c}20-25 \\
24 \pm 2.1 \\
25\end{array}$ & $0.001 *$ \\
\hline $\begin{array}{l}\mathbf{4 0 0 0 ~ H z} \\
\text { Range } \\
\text { Mean } \pm \text { SD } \\
\text { Median } \\
\end{array}$ & $\begin{array}{c}25-50 \\
38.7 \pm 8.5 \\
40 \\
\end{array}$ & $\begin{array}{c}20-35 \\
25 \pm 6.5 \\
20 \\
\end{array}$ & $0.001 *$ \\
\hline $\begin{array}{l}8000 ~ H z \\
\text { Range } \\
\text { Mean } \pm \text { SD } \\
\text { Median }\end{array}$ & $\begin{array}{c}30-50 \\
44 \pm 5.4 \\
45\end{array}$ & $\begin{array}{c}20-50 \\
32.6 \pm 9.4 \\
30\end{array}$ & $0.001 *$ \\
\hline
\end{tabular}

Wilcoxon signed ranks test for comparing preoperative and post-operative

$*$ : Significant difference in between groups ( $\mathrm{p}$ value $\leq 0.05$ )

Table (5): Comparison between preoperative and postoperative pure tone audiometry in group B $(\mathbf{n}=15)$.

\begin{tabular}{|c|c|c|c|}
\hline Frequency $(\mathrm{Hz})$ & $\begin{array}{c}\text { Preoperative pure tone } \\
\text { audiometry }\end{array}$ & $\begin{array}{c}\text { Postoperative pure tone } \\
\text { audiometry }\end{array}$ & P - value \\
\hline $\begin{array}{l}250 \mathbf{~ H z} \\
\text { Range } \\
\text { Mean } \pm \text { SD } \\
\text { Median }\end{array}$ & $\begin{array}{c}35-60 \\
48.3 \pm 8.8 \\
50\end{array}$ & $\begin{array}{c}25-40 \\
33 \pm 6.8 \\
35\end{array}$ & $0.001^{*}$ \\
\hline $\begin{array}{l}\mathbf{5 0 0} \mathbf{~ H z} \\
\text { Range } \\
\text { Mean } \pm \text { SD } \\
\text { Median } \\
\end{array}$ & $\begin{array}{c}25-60 \\
46.3 \pm 12.4 \\
50\end{array}$ & $\begin{array}{c}20-45 \\
31.3 \pm 8.1 \\
35\end{array}$ & $0.001 *$ \\
\hline $\begin{array}{l}1000 ~ H z \\
\text { Range } \\
\text { Mean } \pm \text { SD } \\
\text { Median }\end{array}$ & $\begin{array}{c}25-50 \\
41.3 \pm 10 \\
45\end{array}$ & $\begin{array}{c}20-40 \\
30.6 \pm 7 \\
35\end{array}$ & $0.001^{*}$ \\
\hline $\begin{array}{l}\mathbf{2 0 0 0 ~ H z} \\
\text { Range } \\
\text { Mean } \pm \text { SD } \\
\text { Median }\end{array}$ & $\begin{array}{c}30-70 \\
43.3 \pm 13.2 \\
40\end{array}$ & $\begin{array}{c}20-55 \\
34 \pm 9.7 \\
35\end{array}$ & $0.001^{*}$ \\
\hline $\begin{array}{l}\mathbf{4 0 0 0 ~ H z} \\
\text { Range } \\
\text { Mean } \pm \text { SD } \\
\text { Median }\end{array}$ & $\begin{array}{c}30-70 \\
46.6 \pm 15.2 \\
40\end{array}$ & $\begin{array}{c}25-65 \\
36 \pm 15.4 \\
30\end{array}$ & $0.001 *$ \\
\hline $\begin{array}{l}8000 \mathbf{H z} \\
\text { Range } \\
\text { Mean } \pm \text { SD } \\
\text { Median }\end{array}$ & $\begin{array}{c}35-90 \\
54 \pm 24 \\
40\end{array}$ & $\begin{array}{c}25-80 \\
45 \pm 22.4 \\
35\end{array}$ & $0.001 *$ \\
\hline
\end{tabular}

Wilcoxon signed ranks test for comparing preoperative and post-operative

*: Significant difference in between groups ( $\mathrm{p}$ value $\leq 0.05$ ) 
Table (6): Comparison between the two groups regarding hearing gain

\begin{tabular}{|c|c|c|c|}
\hline Frequency $(\mathrm{Hz})$ & $\begin{array}{c}\text { Group A } \\
\text { Half thickness graft }(n=15)\end{array}$ & $\begin{array}{c}\text { Group B } \\
\text { Full thickness graft }(n=15)\end{array}$ & $P$ - value \\
\hline $\begin{array}{l}250 \mathbf{~ H z} \\
\text { Range } \\
\text { Mean } \pm \text { SD } \\
\text { Median }\end{array}$ & $\begin{array}{c}5-25 \\
16.3 \pm 6.9 \\
15\end{array}$ & $\begin{array}{c}10-25 \\
15.3 \pm 5.5 \\
15\end{array}$ & 0.593 \\
\hline $\begin{array}{l}\mathbf{5 0 0} \mathbf{~ H z} \\
\text { Range } \\
\text { Mean } \pm \text { SD } \\
\text { Median } \\
\end{array}$ & $\begin{array}{c}15-25 \\
18.3 \pm 3.6 \\
20\end{array}$ & $\begin{array}{c}5-25 \\
15 \pm 6.8 \\
15\end{array}$ & 0.280 \\
\hline $\begin{array}{l}\mathbf{1 0 0 0 ~ H z} \\
\text { Range } \\
\text { Mean } \pm \text { SD } \\
\text { Median } \\
\end{array}$ & $\begin{array}{c}0-25 \\
10 \pm 7.5 \\
10\end{array}$ & $\begin{array}{c}5-20 \\
10.7 \pm 5 \\
10 \\
\end{array}$ & 0.573 \\
\hline $\begin{array}{l}\mathbf{2 0 0 0 ~ H z} \\
\text { Range } \\
\text { Mean } \pm \text { SD } \\
\text { Median } \\
\end{array}$ & $\begin{array}{c}0-15 \\
10 \pm 6 \\
15\end{array}$ & $\begin{array}{c}5-20 \\
9.3 \pm 5.6 \\
5 \\
\end{array}$ & 0.693 \\
\hline $\begin{array}{l}\mathbf{4 0 0 0 ~ H z} \\
\text { Range } \\
\text { Mean } \pm \text { SD } \\
\text { Median } \\
\end{array}$ & $\begin{array}{c}5-20 \\
13.7 \pm 4.4 \\
15 \\
\end{array}$ & $\begin{array}{c}5-15 \\
10 \pm 4.6 \\
10 \\
\end{array}$ & $0.037 *$ \\
\hline $\begin{array}{l}\mathbf{8 0 0 0 ~ H z} \\
\text { Range } \\
\text { Mean } \pm \text { SD } \\
\text { Median } \\
\end{array}$ & $\begin{array}{c}0-25 \\
11.3 \pm 8.3 \\
10 \\
\end{array}$ & $\begin{array}{c}0-20 \\
9 \pm 6 \\
10 \\
\end{array}$ & 0.479 \\
\hline
\end{tabular}

Mann-Whiteny test was used for quantitative data

*: Significant difference in between groups ( $p$ value $\leq 0.05$ )

In one study using full thickness composite cartilage island grafts in type I tympanoplasty, successful Graft take was achieved in $97.29 \%$ with mean postoperative pure-tone average air-bone gap improvement of $20.2 \mathrm{~dB}$ at $500 \mathrm{~Hz}$, $23.58 \mathrm{~dB}$ at $1000 \mathrm{~Hz}, 22.23 \mathrm{~dB}$ at 2000 $\mathrm{Hz}$, and 24.79 at $4000 \mathrm{~Hz} .{ }^{11}$

On the other hand, another study with 15 patients, the mean postoperative gains in air-bone gap were $11.9 \mathrm{~dB}$ with the cartilage island. ${ }^{12}$ A third study of full thickness cartilage island graft in 60 patients showed postoperative Air Bone gaps of 17.12, 16.48, 12.32, 9.09 and $7.19 \mathrm{~dB}$ at 250, 500, 1000, 2000, and $4000 \mathrm{~Hz}{ }^{13}$

In a study of 1,000 patients, the average pre- and postoperative air bone gap (ABG) were $21.7 \pm 13.5 \mathrm{~dB}$ and 11.9 $\pm 9.3 \mathrm{~dB}(\mathrm{p}<0.05)$ in 215 cases of highrisk perforation. Complications included recurrent perforation (4.2\%), conductive hearing loss requiring revision in $1.9 \%$, postoperative \& intra operative tube insertion in four $(1.9 \%)$ and six ears (2.8), respectively. ${ }^{6}$
Overbosch (1971) was the first to describe a microslice technique to improve the acoustic properties of the reconstructed TM, using a dermatome, he cut the cartilage into a plate with a thickness of 0.1 to $0.2 \mathrm{~mm}$. Currently, thin cartilage plates are used for reconstructing total TM defects and for protecting total or partial ossicular replacement prosthesis implants underneath the TM, cartilage is well tolerated by the TM, can be placed under some degree of tension beneath the graft, and has a very low risk of extrusion. ${ }^{14}$

In an experimental study, it was suggested that reducing the thickness of the cartilage slices to less than 500 micrometers gives acoustic properties similar to the tympanic membrane. ${ }^{15}$ In our study, the success rate with our technique was $93.8 \%$, we have used thin cartilage in group A where the approximate thickness is $0.5 \mathrm{~mm}$ (half thickness). In group B, thinning was not done where approximate thickness is 1.0 mm (full thickness). 
In this study, there was an improvement in healing and hearing in both groups. In both groups, there was a statistically significant difference in preoperative and postoperative PTA which showed more improvement in hearing postoperatively $(\mathrm{p}=0.001)$, but hearing gain was better in group A (half thickness) than group B (full thickness). The difference in hearing gain, between group A and B at all frequencies was not statistically significant except at 4000 Hz. There was a statistically significant difference in hearing gain between group A and group B, only at frequency $4000 \mathrm{~Hz}$, Group A having more hearing gain. $(\mathrm{p}=0.037)$.

One study ${ }^{16}$, used thin cartilage similar to our group A where the approximate thickness was $0.45 \mathrm{~mm}$. In group B, thinning was not done, and the approximate thickness was $0.9 \mathrm{~mm}$. In this study, the cartilage shield technique has been modified as well. The graft take-up rates are excellent for both partial and full thickness tragal cartilage material in modified cartilage shield technique of tympanoplasty. Difference in hearing gain was not statistically significant between the two groups, except at $4,000 \mathrm{~Hz}$ where hearing gain in partial thickness tragal cartilage recipients (Group A) is more than full thickness tragal cartilage recipients (Group B). For both group A and B, hearing gain is more at all other frequencies tested. ${ }^{16}$

A total number of 223 ears underwent type 1 cartilage tympanoplasty using shield sliced tragal cartilageperichondrium composite graft. ${ }^{4}$ Patients ranged from 11- to 57-year age group. The total number of males is 129 , and for females, it was 94 . The success rate in terms of perforation closure in 11- to 20 -year age group was $97.7 \%$; 21 - to 40 year age group. $99.1 \%$, and 4-60-year age group, $96.96 \% .{ }^{4}$ The success rate with this technique was $98.2 \%$ in terms of perforation closure the average (SD)
ABG closure postoperatively was $7.06 \pm$ $3.39 \mathrm{~dB}$. The average ABG closure of 7 $\mathrm{dB}$ is indicative of the effective sound conduction by the sliced cartilage graft. Hence, slicing cartilage has offset the disadvantage of the thicker cartilage interfering with the sound conduction. ${ }^{4}$

\section{Conclusions:}

Our data show that slicing of the tragal cartilage into a half-thickness tragal cartilage $(0.5 \mathrm{~mm})$ is suitable to improve the sound transmission properties of the reconstructed tympanic membrane in comparison to a full thickness tragal cartilage (1.0 $\mathrm{mm})$. So that it gives good anatomical and functional results among Egyptian patients. We recommend using a sliced cartilage as a first choice for tympanic membrane reconstruction.

\section{Conflict of interest:_None}

Funding Sources: This study was supported by personal funds and funds from Minia University.

Ethical approval: "All procedures performed in this study followed the 1964 Helsinki declaration and its later amendments and was approved by the local research ethics committee at Minia Faculty of Medicine. Informed consent was obtained from all the study participants.

\section{Reference:}

1. Adkins WY (1990) Composite autograft for tympanoplasty and tympanomastoid surgery. The Laryngoscope 100 (3):244-247

2. Buckingham RA (1992) Fascia and perichondrium atrophy in tympanoplasty and recurrent middle ear atelectasis. Annals of Otology, Rhinology \& Laryngology 101 (9):755758

3. Khan MM, Parab SR (2015) Average thickness of tragal cartilage for slicing techniques in tympanoplasty. The Journal of laryngology and otology 129 
(5):435-439.

doi:10.1017/S0022215115000055

4. Khan MM, Parab SR (2011) Primary cartilage tympanoplasty: our technique and results. American journal of otolaryngology 32 (5):381-387

5. Ergun O, Bajin M, Sargon M, Sennaroglu L (2017) Hacettepe cartilage slicer: a novel cartilage slicer and its performance test results. The Journal of Laryngology \& Otology 131 (8):671-675

6. Dornhoffer J (2003) Cartilage tympanoplasty: Indications, techniques, and outcomes in A 1,000-patient series. The Laryngoscope 113 (11):1844-1856

7. Murbe D, Zahnert T, Bornitz M, Huttenbrink KB (2002) Acoustic properties of different cartilage reconstruction techniques of the tympanic membrane. The Laryngoscope 112 (10):1769-1776. doi:10.1097/00005537-20021000000012

8. Mohamad SH, Khan I, Hussain SM (2012) Is cartilage tympanoplasty more effective than fascia tympanoplasty? A systematic review. Otology \& Neurotology 33 (5):699-705

9. Lee CF, Chen JH, Chou YF, Hsu LP, Chen PR, Liu TC (2007) Optimal graft thickness for different sizes of tympanic membrane perforation in cartilage myringoplasty: a finite element analysis. The Laryngoscope 117

(4):725-730. doi:10.1097/mlg.0b013e318031f0e7

10.Yung M (2008) Cartilage tympanoplasty: literature review. The Journal of laryngology and otology 122 (7):663-672. doi:10.1017/S0022215108001813

11.Karaman E, Duman C, Isildak H, Enver O (2010) Composite cartilage island grafts in type 1 tympanoplasty: audiological and otological outcomes.
The Journal of craniofacial surgery 21 (1):37-39. doi:10.1097/SCS.0b013e3181c36283

12.Kirazli T, Bilgen C, Midilli R, Ogut F (2005) Hearing results after primary cartilage tympanoplasty with island technique. Otolaryngology--head and neck surgery: official journal of American Academy of Otolaryngology-Head and Neck Surgery $132 \quad$ (6):933-937. doi: 10.1016/j.otohns.2005.01.044

13. Kalcioglu MT, Firat Y, Selimoglu E (2009) Cartilage Tympanoplasty with Island Technique: A Comparison with the Temporalis Muscle Fascia Technique. Journal of International Advanced Otology 5 (1(

14.Overbosch H (1971) Homograft myringoplasty with micro-sliced septal cartilage. Practica oto-rhinolaryngologica 33 (5):356

15.1Zahnert T, Hüttenbrink K-B, Mürbe D, Bornitz M (2000) Experimental investigations of the use of cartilage in tympanic membrane reconstruction. Otology \& Neurotology 21 (3):322-328

16. Vadiya S, Bhatt S (2016) Comparison of Partial Thickness and Full Thickness Tragal Cartilage Graft During Modified Cartilage Shield Tympanoplasty for Type I Procedures. Indian journal of otolaryngology and head and neck surgery: official publication of the Association of Otolaryngologists of India $68 \quad(1): 30-33$. doi:10.1007/s12070-015-0830-y 